\title{
PREVENTIVE WAR AND THE LESSONS OF HISTORY
}

\author{
Jules Lobel
}

In September 2002, as the Bush administration was gearing up for a showdown with Iraq, the White House released its National Security Strategy, which announced a radical shift in American military policy. ${ }^{1}$ The United States had previously adhered doctrinally, if not always in practice, to the international rule that a nation may unilaterally launch a military attack against another nation only in strict self-defense, that is, in response to an armed attack or an imminent threat of an armed attack. ${ }^{2}$ Any other use of military force requires approval of the United Nations ("U.N.") Security Council, which must first find that a "threat to the peace, breach of peace, or act of aggression" exists, and then must authorize the use of force to remove that threat. ${ }^{3}$ The 2002 National Security Strategy maintained that the threat of catastrophic attacks with weapons of mass destruction by rogue states and/or terrorists demands a new, preemptive approach. ${ }^{4}$ The new doctrine insisted that unilateral recourse to war is justified not only to forestall imminent attacks, but to preempt non-imminent threats where the threats are large enough. ${ }^{5}$ The United States led invasion of Iraq was widely viewed as the first test of this preemptive war doctrine.

The legality of the Iraq war and the administration's preemptive war doctrine has been hotly debated. Thousands of pages have been written in law reviews discussing whether the war was legally justified under the U.N. Charter (the "Charter") or under customary international law. ${ }^{6}$ The legal

* Professor of Law, University of Pittsburgh Law School. This Article draws upon a larger book project, co-authored with Professor David Cole, entitled Less Safe Less Free: The Failure of Preemption in the War on Terror (forthcoming New Press 2007) (see particularly Chapter 7). Any mistakes or errors are, of course, my own, as are any views expressed in this Article. I wish to thank my research assistant Sarah Vuong for her research help with this Article and the staff of the Document Technology Center at the University of Pittsburgh for their invaluable assistance in preparing this Article.

1. The White House, The National Security Strategy of the United States of America (2002), available at http://www.whitehouse.gov/ncs/nss.pdf [hereinafter NATIONAL SECURITY STRATEGY].

2. Jules Lobel, Benign Hegemony? Kosovo \& Article 2(4) of the U.N. Charter, 1 CHI. J. InT'L L. 19, 20-22 (2000). John Yoo, Using Force, 71 U. Chi. L. Rev. 729, 735 (2004).

3. U.N. CHARTER arts. 39-51.

4. See National Security Strategy, supra note 1, at 15.

5. See id.

6. See, e.g., William Bradford, "The Duty to Defend Them": A Natural Law Justification for the Bush Doctrine of Preventive War, 79 Notre Dame L. Rev. 1365 (2004); Lori Fisler Damrosch \& Bernard 
debate has focused on questions of whether international law permits unilateral recourse to war to forestall non-imminent threats where the threats are large enough, and whether the Iraq invasion was legally authorized by prior Security Council resolutions.

Virtually ignored by legal scholars in this debate is the substantial history of European warfare launched to preempt perceived gathering threats and the lengthy post-Cold War discussion among United States policymakers as to the advisability of the United States launching preventive wars against the Soviet Union or other communist states. ${ }^{7}$ The absence of this history from the legal discourse on the Iraq war seems curious, for international law scholars often turn to historical precedent to interpret legal norms. Perhaps the explanation lies in the nature of this history of preventive war thinking, in which leaders have considered the advisability of the resort to war rather than its legality, an inquiry which might be thought best left for political scientists or historians, not lawyers. Typically, international legal scholars focus their analysis of history on a fairly narrow search for precedents where governments act upon and articulate their view of the relevant law, rather than governmental debates over the efficacy of particular policies. ${ }^{8}$ Therefore, it is not surprising that the two examples of preventive use of force relied on in recent legal discourse, the 1981 Israeli attack on the Iraqi nuclear reactor and President Kennedy's quarantine during the Cuban Missile Crisis, are those where states invoked their interpretation of the Charter's legal regime involving use of force. ${ }^{9}$

Yet the lengthy history in Europe and the United States of preventive war thinking seems highly relevant to a discussion of the administration's main justification for its preventive war doctrine: it will make us and the world

H. Oxman, Agora: Future Implications of the Iraq Conflict, 97 AM. J. InT'L LAw 553, 803 (2003); Sean D. Murphy, Assessing the Legality of Invading Iraq, 92 GEo. L.J. 173 (2004); Winton P. Nagan \& Craig Hammer, The New Bush National Security Doctrine and the Rule of Law, 22 Berkeley J. INT'L L. 375 (2004); Joel R. Paul, The Bush Doctrine: Making or Breaking Customary International Law?, 27 Hastings Int'L \& Comp. L. Rev. 457 (2004); Jorge Alberto Ramirez, Iraq War: Anticipatory Self-Defense or Unlawful Unilateralism, 34 CAL. W. INT'L L.J. 1 (2003); Yoo, supra note 2, at 729.

7. A LexisNexis search of law review articles on the Iraq war or 2002 National Security Strategy has uncovered almost no mention of this history. The author conducted a search using the terms "Iraq War" or "2002 National Security Strategy." Such search returned 1121 articles covering these topics; however, there was no mention of the lengthy history of preventive war.

8. See, e.g., Jules Lobel \& Michael Ratner, Bypassing the Security Council: Ambiguous Authorizations to Use Force, Cease-fires and the Iraqi Inspection Regime, 93 AM. J. InT'L L. 124 (1999); Paul, supra note 6; Nagan \& Hammer, supra note 6.

9. Patrick McLain, Note, Settling the Score with Saddam: Resolution 1441 and Parallel Justifications for the Use of Force Against Iraq, 13 DukE J. CoMP. \& INT'L L. 233, 269 (2003); Yoo, supra note 2, at 761-65. 
safer. Undoubtedly, the administration's doctrine fits uncomfortably within the current legal regime regulating resort to war, and most international law scholars, most nations of the world, and the U.N. General Secretary Kofi Anan viewed the Iraq war as illegal. ${ }^{10}$ Nonetheless, administration supporters argue that the U.N. Charter's rules do not provide the United States with security against nations we claim are "rogue states." While the Charter and customary international law mandate that a nation not unilaterally use armed force unless it is attacked or at least is facing an imminent threat of attack, President Bush has stated that we must act before threats are "fully formed," 12 for "if we wait for threats to fully materialize, we will have waited too long." 13 Therefore, the administration argues that we must either discard or radically alter the traditional imminence requirement of customary international law to allow a nation to use force in self-defense when it believes a high likelihood of future attack exists, even if the perceived attack is not temporally imminent. ${ }^{14}$ The administration claims that we can no longer rely on the defensive postures of the past which comported with the traditional requirements of international law because deterrence does not work against rogue states. "Containment is not possible," proclaimed President Bush at West Point in 2002, "when unbalanced dictators with weapons of mass destruction can deliver those weapons on missiles or secretly provide them to terrorist allies." 15

The administration's arguments that national security requires that we not wait for gathering dangers to materialize, but use force preemptively to forestall a future attack echoes arguments made by government and military leaders throughout history in a variety of strategic environments. ${ }^{16}$ While these arguments were made in different strategic contexts, they invariably emphasized the newness of the threats the nation faced, the inevitability of a future attack, and the inordinate cost of waiting until the other side either

10. Iraq War Illegal, says Annan, BBC News, Sept. 16, 2004, available at http://news.bbc.co.uk/ 2/hi/middle_east/3661134.stm; Anne Penketh \& Andrew Grice, Blix: Iraq War was Illegal, InDEPENDENT, Mar. 5, 2004; Ignacio Ramonet, Lawless War, Le Monde Diplomatique, Apr. 2003; PeterFord, As Attack on Iraq Begins, Questions Remain: Is it Legal?, Christian SCIEnCE Monitor, Mar. 21, 2003; Richard Norton-Taylor, Law unto Themselves, Guardian, Mar. 13,2003; Tearing Up the Rules: The Illegality of Invading Iraq, Center for Economic and Social Rights, Emergency Campaign on Iraq, Mar. 2003.

11. Yoo, supra note 2, at 745-50.

12. National Security Strategy, supra note 1, at preface.

13. Press Release, The White House, President Bush Delivers Graduation Speech at West Point (June 1, 2002), available at $\mathrm{http}: / / \mathrm{www} . w h i t e h o u s e . g o v /$ news/2002/06/20020601-3.html.

14. Yoo, supra note 2, at 750.

15. National Security Strategy, supra note 1, at preface.

16. See discussion infra. 
attacked or attack was imminent. ${ }^{17}$ This history offers valuable lessons for our own era.

This article will not revisit the arguments made for or against the legality of the Iraq war, nor the Bush administration preemptive war doctrine that justified it. Rather, it will evaluate the administration's arguments against the backdrop of history. Of course, the historical terrain is contested and fails to provide definitive answers. Context matters, and every strategic environment presents new problems and challenges. Nevertheless, the preventive war arguments underlying the Iraq war have a rich and lengthy history that seems highly relevant for both understanding the legal rules contained in the U.N. Charter and assessing their continued relevance.

This article therefore uses history in a very different manner than that customarily used by international legal scholars. Rather than analyzing state practice to determine the content of international law, history is used here to understand the dangers of the administration's doctrine and the reasons that underlie its rejection by the framers of the U.N. Charter. Legal norms undoubtedly seek to encapsulate historical experience, and while the lessons of history certainly can and have been misused, abused, and misunderstood, history ought not to be simply ignored. That the history speaks to the wisdom of a particular sort of policy and not its legality ought not to lead to its legal irrelevance, particularly in an era in which the applicable legal norms are under assault as being inconsistent with national security requirements. ${ }^{18}$

Nor is the search for historical meaning in this area misguided because, as one commentator has argued, a nation's use of force occurs in "exceptional, singular contexts," in which each "specific set of circumstances" presents different problems, and therefore, learning from experience may not play a useful role. ${ }^{19}$ Whether that is true is better understood after an examination of the historical record, to determine whether some general trends or principles can, in fact, be discerned.

The first test of the administration's newly-minted doctrine in Iraq has undoubtedly been a disaster. ${ }^{20}$ By virtually all accounts, the war has made the United States and the world less safe. ${ }^{21}$ The war was fought unnecessarily to

17. $I d$.

18. See, e.g., Yoo, supra note 2.

19. Richard J. Pildes, The Dark Side of Legalism, 44 VA. J. INT'L L. 145, 154 (2003).

20. James A. Baker, III \& Lee H. Hamilton, Co-Chairs, The Iraq Study Group Report 27, The United States Institute for Peace (2006).

21. Daniel Benjamin, Why Iraq Has Made Us Less Safe, Time, July 21, 2005. 
destroy dangerous weapons that turned out to be nonexistent. ${ }^{22}$ The war has created a terrorist haven in Iraq where none existed before, has cost thousands of lives and billions of dollars, has sparked an insurgency that threatens to spiral into full scale civil war, and has emboldened other "rogue states" by sending a message to countries such as Iran and North Korea that they should accelerate their development of weapons of mass destruction in order to deter another "preventive" attack by the United States. ${ }^{23}$ But perhaps the administration simply got it wrong and attacked the wrong country, for the wrong reasons, at the wrong time. While the debacle in Iraq ought to provide a strong cautionary example for advocates of preventive war, it does not necessarily disprove the utility or logic of other preventive attacks against other governments viewed as rogue states.

Yet the history of preventive warfare outlined in this article illustrates that often such wars prove to be both unnecessary and disastrous. International law makes the judgment that it is better to avoid warfare unless a nation is being attacked or facing imminent attack, or can convince the Security Council that there is no other viable response to a serious threat to peace but to use force. The historical record of prior preventive wars and United States policymakers' discussions of proposed preventive wars during the Cold War suggests that the judgment the law makes is reasonable.

\section{The History of Preventive Warfare}

The Bush administration presents its preventive war doctrine as a new doctrine for a new world. ${ }^{24}$ The National Security Strategy states that after September 11 we are living in a "new world," where we "can no longer solely rely on a reactive posture as we have in the past." ${ }^{.25}$ President Bush termed his strategy a "new doctrine called pre-emption," 26 arguing that the war against terrorism ushers in a "new paradigm." 27

\footnotetext{
22. Douglas Jehl, Inspector's Report to Detail Iraqi Plans to Undermine and Produce Illicit Arms, N.Y. Times, Oct. 5, 2004, at A10.

23. Dana Priest, Iraq New Terrorist Breeding Ground, WASH. Post, Jan. 14, 2005, at A1; Martin Wolk, Cost of War Could Surpass \$1 Trillion, MSNBC, Mar. 17, 2006; Head of U.S. Command: Iraq Civil War Possible, CNN.com, Aug. 3, 2006; Mark Mazatti, Spy Agencies Say Iraq War Worsens Terrorism Threat, N.Y. Times, Sept. 24, 2006, at § 1, 1.

24. Press Release, supra note 13.

25. National Security Strategy, supra note 1 , at 15.

26. Id.

27. Memorandum from President George W. Bush, President of the U.S. to The Vice President of the U.S., The Sec'y of State of the U.S., The Sec'y of Def. of the U.S., The Att'y Gen. of the U.S., Chief
} 
In one sense, the doctrine is new. It is inconsistent with the rules set forth in the U.N. Charter, which the United States had previously adhered to as a matter of official policy, if not always in practice. ${ }^{28}$ As Secretary of State Daniel Webster put it in 1842, preemptive self-defense is permitted only where the threat is "instant, overwhelming, leaving no choice of means and no moment of deliberation. ${ }^{29}$ Until recently, the United States accepted this imminence standard. Thus, the Pentagon's definition of lawful preemptive self-defense echoed Webster's: "an attack initiated on the basis of incontrovertible evidence that an enemy attack is imminent." 30

The principle that individual nations may unilaterally use military force against another nation only in self-defense is designed to reduce resort to war by insisting on a bright line. ${ }^{31}$ An armed attack is an objective fact; an imminent attack involves some amount of prediction, but is generally understood to require objective evidence that the attack is indeed imminent, such as the massing of troops at the border. ${ }^{32}$ The new Bush doctrine of "preemption" departs from this bright-line rule and substitutes a theory more accurately described as one of "preventive war" that permits the use of force on the basis of a much more open-ended and less objectively verifiable standard..$^{33}$ According to the Pentagon, preventive war is "a war initiated in the belief that military conflict, while not imminent, is inevitable, and that to delay would involve greater risk." ${ }^{\prime 34}$ That description aptly fits the Iraq war, as no administration official argued that Iraq had plans to attack the United States or anybody else imminently. Rather, the administration's claims were based on a calculation of inevitability or probability. Deputy Secretary of

of Staff to the President of the U.S., Dir. of Cent. Intelligence of the U.S., Assistant to the President for Nat'l Sec. of the U.S. (Feb. 7, 2002), a vailable at http://www.gwu.edu/ nsarchiv/NSAEBB/NSAEBB127/ 02.02.07.pdf; see also NATiOnal Security StRATEgy, supra note 1, at preface ("In the new world we have entered, the only path to peace and security is the path of action.").

28. Yoo, supra note 2, at 729, 735.

29. Daniel Webster, The Works of Daniel Webster 301-02 (1851).

30. Joint Chiefs of Staff, Department of Defense Dictionary of Military and Associated TERMS 421 (2001), available at http://www.dtic.mil/doctrine/jel/new_pubs/jp1_02.pdf.

31. U.N. CHARTER art. 51, available athttp://www.un.org/aboutun/charter/ ("Nothing in the present Charter shall impair the inherent right of individual or collective self-defence if an armed attack occurs against a Member of the United Nations, until the Security Council has taken measures necessary to maintain international peace and security. Measures taken by Members in the exercise of this right of selfdefence shall be immediately reported to the Security Council and shall not in any way affect the authority and responsibility of the Security Council under the present Charter to take at any time such action as it deems necessary in order to maintain or restore international peace and security.").

32. National Security Strategy, supra note 1, at 15.

33. Id.

34. Joint Chiefs of StafF, supra note 30, at 423. 
State Richard Armitage asserted that rogue states' "unrelenting drive to possess weapons of mass destruction brings about the inevitability that they will be used against us or our interests." ${ }^{35}$

However, President Bush's doctrine of preventive war is not new in that it has a very ancient and sordid pedigree. Just as the domestic use of preventive detention to preempt perceived threats has had a troubled history, so too, the use of preventive war to preempt external gathering dangers before they come to pass has often had calamitous consequences. The history of Western civilization is filled with major wars commenced for preventive reasons: Sparta's declaration of war against Athens commencing the Peloponnesian War, Carthage's preemptive attack on Rome, the preventive war declared by Germany against Russia that initiated World War I, or Japan's surprise attack on the American fleet at Pearl Harbor. ${ }^{36}$ Most of these wars were launched by leaders who also perceived that the strategic environment their nations faced was new, and required decisive action before the new gathering threats inevitably eventuated. ${ }^{37}$

The framers of the U.N. Charter sought in 1945 to limit a nation's discretion to use force to prevent perceived dangers. At the founding San Francisco Conference of the U.N., the U.S. delegation introduced the language which allowed for a right of self-defense only "if an armed attack occurs." 38 In response to concerns that this might limit the right of self-defense too severely, a leader of the American delegation, Governor Harold Stassen, replied that "this was intentional and sound.... We did not want exercised the right of self-defense before an armed attack had occurred." ${ }^{39}$

The U.N. Charter's prohibition on the use of force for any reason other than self-defense stemmed from the world's experience with preventive war during World War I and World War II. As political scientist David Hendrickson observes, "[r]epugnance for preventive war became deeply embedded in the world community because the use of that doctrine in the twentieth century led to results nearly fatal to civilization. ${ }^{, 40}$

35. Jeffrey Record, Dark Victory: America's Second War Against Iraq 32 (2004).

36. Copeland, infra note 54, at 116, 211, 212-13; James McPherson, The Fruits of Preventive War, Am. Hist. Ass'N, May 2003.

37. See discussion infra.

38. Foreign Rel. OF THE U.S. 1945, at 813, 818 (1945).

39. Id.

40. David C. Hendrickson, Imperialism versus Internationalism: The United States and World Order, Gaiko Forum, Fall 2002, at 36. 
Many historians view World War I as a preventive war. ${ }^{41}$ On June 28, 1914, the Archduke Francis Ferdinand of Austin was assassinated by a Serb revolutionary in the Bosnian capital of Sarejevo. A short five weeks later, the major European powers were at war, a war in which ten million people were killed, more than twice as many as had died in all the wars of the previous two centuries. ${ }^{42}$ The war brought chaos and disorder to Europe, and ultimately led to the dissolution of three great empires - the Russian, Austrian Hungarian and Ottoman Empires. ${ }^{43}$

An important ideological and strategic cause of the war was the increasing turn towards preventive war reasoning by all the great powers in the first decades of the 20th century. ${ }^{44}$ This widespread acceptance of preventive war doctrine, a consequence of the increasing fears wrought by the rapid pace of technological and social change, was most pronounced in Germany. ${ }^{45}$

Germany had not always been this way. Forty years earlier, then German Chancellor Otto von Bismarck had strongly argued against the doctrine of preventive war. No dove, Bismarck was known for his leadership of Germany during three wars leading to German unification and argued that great political questions would be decided "by blood and iron." ${ }^{.46}$ Nonetheless, throughout the 1870s and 1880s Bismarck urged a policy of caution and patience and attempted to maintain friendly relations with Russia. Bismarck repeatedly opposed the policy of preventive war urged by military leaders such as Count Waldersee, German Chief of Staff. ${ }^{47}$ Bismarck once characterized preventive war as committing "suicide from fear of death, ${ }^{48}$ and told Kaiser Wilhelm I that: "I would ... never advise Your Majesty to declare war forthwith, simply because it appeared that our opponent would begin hostilities in the near future. One can never anticipate the ways of divine providence securely enough for that." ${ }^{\prime 49}$ Nonetheless, by 1890 , Bismarck was forced to resign, and the strategy of preventive war became entrenched as German military doctrine.

\footnotetext{
41. Dan Moran, Preventive War and the Crisis of July, 1914, Strategic Insights (2002).

42. Id.

43. Martin Gilbert, The First World War 523 (Henry Holt New York, 1994).

44. Moran, supra note 41.

45. Id.

46. Fritz Stern, Gold And Iron: Bismarck, Bleichröder, ANd the Building OF the German

47. Gordon A. Craig, The Politics of the Prussian Army 1640-1945, at 268 (1955).

48. Id.; Richard K. Betts, Suicide from Fear of Death?, Foreign AfFAIRS, Jan./Feb. 2003, at 34-35.

49. CRAIG, supra note 47 , at 255 .
} EMPIRE 28 (1977). 
By the turn of the 20th century, German military leaders had concluded that preventive war was essential to the country's long-term security. Germany's generals and some powerful civilian leaders came to believe that war with France and Russia was inevitable, and that time was not on Germany's side because Russia's rapid modernization of its armed forces would soon render Germany incapable of defeating France and Russia in a war. ${ }^{50}$ German Chief of Staff Helmuth von Moltke expressed the widely held view at a high level meeting between Kaiser Wilhelm and military leaders in December 1912 that "war is inevitable, and the sooner the better."

By the spring of 1914, Germany's military and civilian leaders concluded that the time was right to wage a preventive war. Moltke calculated that Germany only had "two or three years" before Russia's national railway network would be sufficiently developed so that rapid Russian mobilization would thwart Germany's ability to prevail against the French-Russian alliance. $^{52}$ The German military plan, developed by General Schlieffen in the 1890 s, relied on a decisive, preemptive attack on France prior to Russian mobilization on Germany's largely unprotected eastern front. ${ }^{53}$ German leaders believed that Russia's rapid armament and technological development put Germany in an untenable position. On the eve of war, German Chancellor Bethmann's secretary and confidant wrote in his diary that "Russia's military power [is] growing rapidly; with the strategic extension [of Russian railways] into Poland the situation is intolerable." ${ }^{\prime 4}$ For the Chancellor and other German leaders, the rapid growth of Russian military power created a specter of "a heavier and heavier nightmare." ${ }^{55}$ The climate of apprehension in Germany before the war was summed up by Germany's Foreign Secretary, who wrote on May 29, 1914:

In two to three years, ... [o]ur enemies' military power would then be so great that [Moltke] did not know how he could deal with it. Now we were still more or less a match for it. In his view there was no alternative but to fight a preventive war so as to beat the enemy while we could still emerge fairly well from the struggle. The Chief of Staff therefore put it to me that our policy should be geared to bringing about an early war. $^{56}$

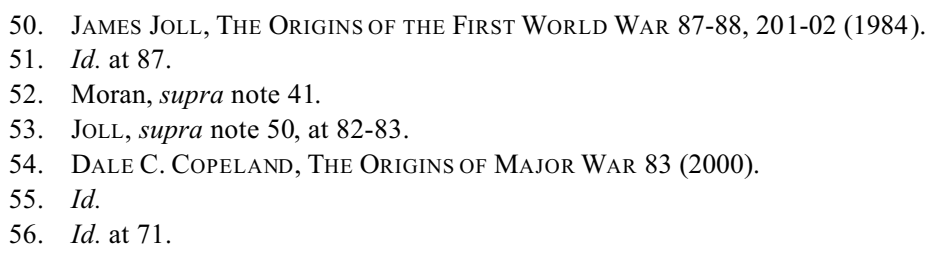


A Serbian assassin's bullet provided the excuse, or in Moltke's words, "an effective slogan" for a preventive war that had already been planned. ${ }^{57}$ In fact, there was little evidence that Russia and France had any plans to attack Germany first. ${ }^{58}$ The preventive war paradigm led German officials such as Chancellor Bethmann to take what he knew was "a calculated risk," a "leap in the dark. ${ }^{" 59}$ The decision proved catastrophic, not only for Germany, but for all of Europe. ${ }^{60}$

Hitler also justified Germany's launching of World War II in preventive terms. In August 1939, he told an assembly of his top military commanders that "we are faced with the hard alternative of either striking or the certainty of being destroyed sooner or later. I am only afraid that some Schwenekind may submit a mediation plan at the last moment." ${ }^{\circ 1}$ German attacks on Norway, Denmark, Holland, Belgium, and eventually the Soviet Union were all justified by Hitler as preventive moves. After the war, in their testimony before the Nuremberg tribunals, the top German military commanders argued that Germany's invasion of Russia was "undeniably a purely preventive war," undertaken "in order to prevent a definite aggression on the part of the adversary," and "the only way out" of the great threat posed by the Soviets. ${ }^{62}$

The founders of the U.N. also had a more recent illustration of the dangers of preventive war: Japan's military strike at Pearl Harbor on December 7, 1941. The Japanese felt cornered by President Roosevelt's freezing of Japanese assets and the U.S. imposition of an oil embargo. ${ }^{63}$ They believed war with the United States was inevitable, and that only by launching a preemptive strike could they avoid defeat. Vice Admiral Yamamoto, Commander in Chief of the Japanese fleet, wrote in a private letter that "[i]n

57. Id. at 72 .

58. Marc Trachtenberg, History and Strategy 67 (1991). Trachtenberg points out that if Germany's goal was to maintain its existing position, that was quite manageable without preventive war. As the German Foreign Secretary admitted in 1912, the British and the French were too committed to peace to ever cause a war, so if Germany did not provoke one "no one else certainly will do so." Id. See also Stephen Van Evera, The Cult of the Offensive and the Origins of the First World War, 9 InTERnATIONAL SeCURITY 58, 69 (1984).

59. Donald Kagan, On the Origins of War and the Preservation of Peace 187, 191 (1995).

60. GiLBeRT, supra note 43, at Xv ("More than nine million soldiers, sailors and airmen were killed in the First World War. A further five million civilians are estimated to have perished under occupation, bombardment, hunger and disease.").

61. Quoted in Alfred Vagts, Defense and Diplomacy: The Soldier and the Conduct of Foreign Relations 315 (1956) [hereinafter Vagts, Defense and Diplomacy].

62. Quoted in Vagts, Defense and Diplomacy, supra note 61, at 319.

63. Walter Lafeber, The American Age: United States Foreign Policy at Home and Abroad Since 1750, at 379 (1989); McPherson, supra note 36. 
the event of outbreak of war with the United States, there would be little prospect of our operations succeeding unless, at the very outset, we can deal a crushing blow to the main force of the American fleet in Hawaiian waters .... .94 The Japanese initially sought to negotiate a diplomatic resolution to the crisis. Nevertheless, when those negotiations proved fruitless, they launched a preventive war. For six months, the Japanese military had unparalleled success; less than four years later, however, two million Japanese were dead and Japanese cities lay smoldering in ruins. ${ }^{65}$

Preventive wars fought by nations to forestall "gathering threats" before they eventuate have often had similar results. The tragic Peloponnesian War from 431404 B.C., fought with unprecedented brutality and causing widespread suffering and destruction, was a preventive war launched by Sparta because of its fear of the threat posed by Athenian power. Sparta faced no immediate threat or direct harm from Athens. Rather, Thucydides wrote that " $[w]$ hat made war inevitable was the growth of Athenian power and the fear which this caused in Sparta."

The Spartan debate over whether to launch a preventive war has a surprisingly modern resonance. Sparta's ally, Corinth, criticized the Spartans for their defensive mindset. The Corinthians claimed that the Spartans were the only Greek peoples who:

do nothing in the early stages to prevent an enemy's expansion; you wait until your enemy has doubled his strength . . . instead of going out to meet [the Athenians], you prefer to stand still and wait until you are attacked, thus hazarding everything by fighting with your opponents who have grown far stronger than they were originally. ${ }^{67}$

The Corinthians argued that Athens presented a new paradigm, a strategic environment "completely different" from anything Sparta had previously faced. ${ }^{68}$ To the Corinthians, Sparta's:

whole way of life [was] out of date when compared with [the Athenians]. And it is just as true in politics as it is in any act or craft: new methods must drive out old ones. When a city can live in peace and quiet, no doubt the old-established ways are best: but when

64. The Pearl Harbor Papers: Inside the Japanese Plans 13 (Donald Goldstein \& Katherine V. Dillon eds., 1993).

65. McPherson, supra note 36.

66. Thucydides, History of the Peloponnesian War 49 (Rex Warner trans., Penguin Books 1972).

67. Id. at 75 .

68. Id. 
one is constantly being faced by new problems, one has also to be capable of approaching them in an original way. ${ }^{69}$

The "original way" was preventive war.

Spartan King Archidamus, who had a reputation for "intelligence and moderation," urged caution, however, because "it is impossible to foresee the course that the war will take." " Archidamus argued that "[a]s for being slow and cautious - which is the usual criticism made against us - there is nothing to be ashamed of in that." ${ }^{, 71} \mathrm{He}$ accurately predicted that the war would not "likely be small scale," and would not "soon be over." impossible to calculate accurately events that are determined by chance,",73 Archidamus suggested that Sparta take a diplomatic course of action because a preemptive attack would have been illegal. He advised "sending a mission" to the Athenians, claiming "this is the right thing to do since the Athenians themselves are prepared to submit to arbitration, and when one party offers this it is quite illegal to attack him first, as though he was definitely in the wrong." 74 Archidamus did not urge appeasement or surrender, but advised that Sparta prepare for the possibility of war while seeking peace.

Archidamus' speech was answered by a Spartan leader, Sthenelaidas, who passionately argued that "this is not a matter to be settled by lawsuits and by words," and called for quick action in support of Sparta's allies, insisting, "Do not allow the Athenians to grow still stronger." 75 The Spartans overwhelmingly followed Sthenelaidas' call for preventive war, despite the fact that Athenian policy was not particularly aggressive, and Athens represented no immediate threat to Sparta. ${ }^{76}$ Sparta's allies voted a month later for war, but not by a large majority. As one scholar puts it "[a]mong the allies, therefore, we may deduce that not everyone thought the war inevitable, not everyone thought it was just, not everyone thought it would be easy and successful, not everyone thought it was necessary." 77 The dissenters had it right.

69. Id. at $76-77$.

70. Id. at 82,84 .

71. Id. at 84 .

72. Id. at $82-83$.

73. Id. at 84-85.

74. Id.

75. Id. at 86 .

76. KAGAN, supra note 59 , at 57.

77. Id. at 58 . 
The preventive thinking that led Sparta to war against Athens has also played a prominent role in many of Europe's most destructive and devastating wars. The war between Carthage and Rome in the 3rd century B.C. that led to the destruction of Carthage "closely follows the preventive logic of the Greek case." "78 Carthage, facing the rise of Rome's power decided to launch a preventive war before it was too late. Hannibal's famous march across the Alps was initially successful, but Carthage wound up losing a devastating war. $^{79}$ So too, post-Westphalian Europe fought many a devastating, destructive and unnecessary preventive war. One study of the major wars in Europe between the 16th and 20th century concludes that virtually all of them were propelled by preventive motivations, in which a powerful but declining state "engaged in a desperate race against time," to defeat the growing danger, which, it perceived, would inevitably overwhelm it. ${ }^{80}$ Another study found that between 1848 and 1918, "[e]very war between Great Powers started as a preventive war, not a war of conquest," and all but one "brought disaster on their originators." ${ }^{\prime 1}$ Yet another analysis of centuries of European warfare finds that "[p]reventive logic . . . is a ubiquitous motive for war." ${ }^{82}$ In 1760, Edmund Burke concluded that the military policy of preventing emerging threats to the balance of power had been the source "of innumerable and fruitless wars" in Europe. ${ }^{83}$

A source of many of these unnecessary and destructive conflicts was exaggerated suspicions about other nations' motives. ${ }^{84}$ Preventive war theory permits nations to act based not simply on an objective, verifiable attack against them, but on a suspicion that such an attack is inevitable in the future. Often, the suspicions turn out to be ill-founded, as occurred in the recent Iraq war. One scholar of warfare concluded after an exhaustive study that the "chief source of insecurity in Europe since modern times . . . lies in the national tendency to exaggerate the dangers they face, and to respond with counterproductive belligerence." ${ }^{85}$ During the height of its power, Rome always perceived itself as in danger of "being attacked by evil minded neighbors, always fighting for breathing space, ${ }^{, 86}$ and launched numerous

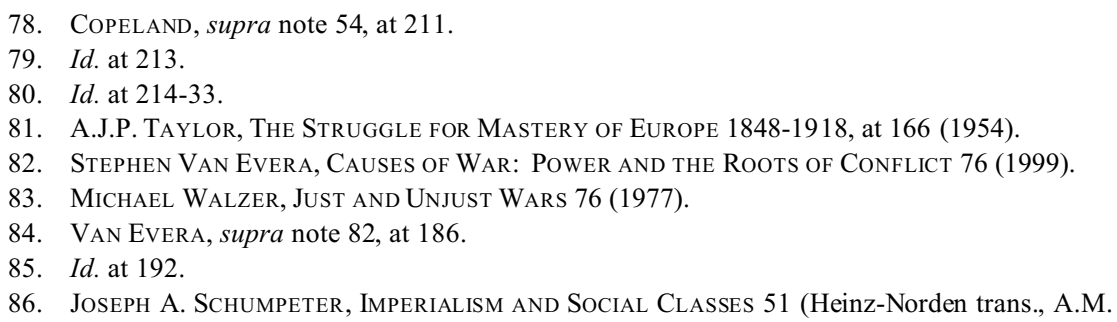


wars motivated by fear and insecurity. The Athenians launched the disastrous Sicilian expedition of 415 because they believed that their security required preventively attacking others and ruling over them to avoid "being subjected to the rule of another party." ${ }^{.87}$ The great Swiss jurist Vattel recognized what seems to be an all too common flaw in these preventive wars when he concludes his discussion of the war fought by Great Britain and its allies against what they believed was King Louis XIV's "design" to dominate Europe on a sobering note: "it has since appeared that the policy [of the Allies] was too suspicious. $"{ }^{88}$

The most destructive and devastating war in United States history also has been viewed by some as a preventive war. As the prominent Civil War historian James McPherson has argued, Southern secession "was a preemptive act to forestall the anticipated threat to slavery." 89 "While Southern moderates argued that they should wait for an "overt act," proponents of secession argued that the South could not afford to wait until the North sent forth more terrorists like John Brown. "If I find a coiled rattlesnake in my path," asked an Alabama editor, "do I wait for an overt act; or do I smite him in his coil?",90 A Mississippian stated the sentiments of many firebrands when he argued, "[1]et us rally before the enemy can make good his promise to overwhelm us. Delay is dangerous. Now is the time to strike." ${ }^{11}$ When Union forces attempted to resupply Fort Sumter-with provisions, not military reinforcements - the Confederates preempted that mission, and fired the shots that started the Civil War. "'It was obvious,' wrote Jefferson Davis, 'that no time was to be lost in . . . anticipating the impending assault' by shooting first." ${ }^{.92}$

Of course, not all preventive wars are failures. ${ }^{93}$ For example, Frederick the Great's preventive 18th century wars propelled the rise of modern Germany. ${ }^{94}$ Caesar's preventive wars were viewed by many Romans as having been undertaken with slight or no provocation, and were seen as unjust

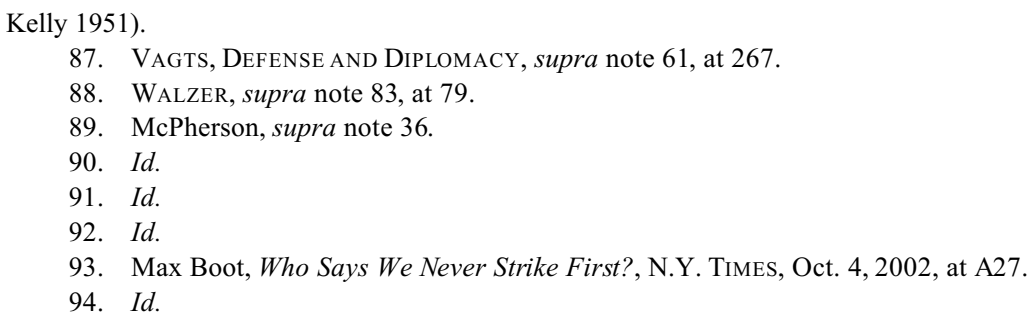


and dangerous, but such objections were overcome because he was enormously successful. ${ }^{95}$

Preventive war proponents also point, however, to the Israel 1981 attack on Iraq's nuclear reactor at Osirak as a recent example of a preventive military strike that made the world safer. ${ }^{96}$ Had Israel not knocked out the Iraqi reactor, administration supporters argue, Saddam Hussein might have already had the bomb by the time he invaded Kuwait. ${ }^{97}$ Israel's clearly unlawful military strike was unanimously condemned by the U.N. Security Council despite Israeli arguments that were similar to, but in hindsight far stronger and more accurate than, those made by the Bush administration in 2003. ${ }^{98}$ The usually hawkish British Prime Minister Margaret Thatcher denounced the raid, stating that "[a]rmed attack in such circumstances cannot be justified. It represents a grave breach of international law." 99 Both the Thatcher government and the Reagan administration joined the Council's strong condemnation. The Reagan administration invoked the Arms Export Control Act, which delayed the delivery of arms it had previously contracted to sell to Israel and required that arms supplied to Israel in the future be used for defensive purposes only. ${ }^{100}$

Nonetheless, the international community imposed only minimal sanctions against Israel, and Israel was able to destroy Iraq's nuclear reactor before it went on line. ${ }^{101}$ While the Israeli strike was certainly a serious shortterm setback to Iraq's nuclear program, its overall success is dubious. Iraq salvaged about 25 kilograms of bomb grade uranium from the rubble, ${ }^{102}$ and Saddam Hussein accelerated his efforts to develop a nuclear weapon. Within several years after the strike, Iraq had up to 20,000 technical workers, including as many as 7,000 scientists and engineers, developing its nuclear

95. VAGTS, DeFENSE AND DiplomACY, supra note 61, at 268.

96. Kenneth M. Pollack, The Threatening Storm 369 (2002).

97. Id.; Craig Gilbert, Can U.S. Be First to Attack Enemy?, Milwaukee Journal Sentinel, Mar. 31, 2002, at $1 \mathrm{~A}$.

98. U.N. SCOR Res. 487, U.N. SCOR, 36th Sess., U.N. Doc. S/RES/487 (1981). at B2.

99. Bruce Ackerman, But What's The Legal Case For Preemption?, WAsh. Post, Aug. 18, 2002,

100. 22 U.S.C. $\S 2754$ (2006) (providing that "[d]efense articles . . . shall be sold . . solely for internal security, for legitimate self-defense ....”); see also Beth M. Polebaum, Note, National Self-Defense in International Law: An Emerging Standard for a Nuclear Age, 59 N.Y.U. L. REV. 187, 187 (1984).

101. Anthony D'Amato, Comment, Israel's Air Strike upon the Iraqi Nuclear Reactor, 77 A.J.I.L. 584, 585-86 (1983).

102. Peter Scott Ford, Israel's Attack on Osiraq: A Model for Future Preventive Strikes 51-52 (Sept. 2004) (unpublished thesis, Naval Postgraduate School) (on file with Library, Naval Postgraduate School). 
weapons program and had expended approximately between $\$ 4$ and $\$ 8$ billion on the work. ${ }^{103}$ Iraqi exile, nuclear scientist Khidir Hamza, told Paul Begala on $\mathrm{CNN}$ that the Israeli strike created "a much larger danger in the longer range."104 Another Iraqi nuclear scientist, Imad Khadduri, claims that the Osirak strike had the exact opposite effect than what Israel intended; it sent Saddam Hussein's A-Bomb program into “overdrive" and convinced the Iraqi leadership to replace the relatively small facility that Israel had bombed with a more massive, full-fledged nuclear program immediately afterwards. ${ }^{105}$ By 1988, after its war with Iran ended, Iraq embarked on building a new array of nuclear facilities, but this time it dispersed and concealed them to prevent another quick airstrike. Indeed, the Osirak raid forced every state seeking nuclear weapons to disperse and conceal its operations, leading one military analyst to conclude that " $t$ the days of Osiraq-type raids on a single, easily located, and above-surface nuclear facility are over." 106 We now know that Iraq, despite the Israeli raid, was perilously close to building a nuclear bomb in 1990. What prevented Iraq from building nuclear weapons was therefore not the Osirak raid, but Hussein's miscalculation in invading Kuwait.

Moreover, as Israel learned, the Osirak strike was hard to replicate. When Pakistan began developing its nuclear program in the 1980s, Israel approached India to request landing and refueling rights for a proposed attack on Pakistan's Kahuta nuclear reactor. ${ }^{107}$ India, despite the grave threat Pakistan's program presented to its people, denied Israel's requests, believing that Kahuta would be very difficult to target and destroy and that Pakistan would respond by attacking India's nuclear facilities, an act that would likely result in a full-scale war. ${ }^{108}$

Preventive war advocates also argue that history demonstrates that the dangers of preventive action are often outweighed by the danger of not acting to preempt a future threat. They point to the 1938 Munich symbol of appeasement where Britain and France abandoned Czechoslovakia to the

103. R. Jeffrey Smith \& Glenn Frankel, Saddam's Nuclear-Weapons Dream: A Lingering Nightmare, WASH. Post, Oct. 13, 1991, at A1; see also Ford, supra note 102, at 51-52.

104. Crossfire (CNN television broadcast Feb. 7, 2003), available at http://transcripts.cnn.com/ TRANSCRIPTS/0302/07/cf.00.html.

105. Id. (quoting Imad Khadduri, IraQ's Nuclear Mirage, Memoirs and Delusions 82 (2003) and Crossfire (CNN television broadcast Feb. 7, 2003), available at http://transcripts.cnn.com/ TRANSCRIPTS/0302/07/cf.00.html).

106. Ford, supra note 102, at 52 (internal citations omitted) (quoting Eliot Cohen).

107. Tom Moriarty, Entering the Valley of Uncertainty: The Future of Preemptive Attack, WorLD AfF., Fall 2004, at 71, 75 (citing Alan McCulley, IsRael AND War 115-20 (1987)).

108. Id. 
Nazis as evidence that the risks of preventive war are counterbalanced by the risks of inaction. ${ }^{109}$ Condoleezza Rice and Donald Rumsfeld argue that millions are dead because Britain and France failed to take preventive military action to thwart the gathering Nazi threat in the 1930s. ${ }^{10}$ But the Munich analogy is inapt, not only because it is ludicrous to claim that Saddam Hussein posed a similar military threat to the United States as did Hitler to Europe in 1938. More fundamentally, Britain and France did not need a doctrine of preventive war to use military force to stop Hitler's military actions against the Rhineland, Austria, or Czechoslovakia. In those instances, they would have been acting to stop armed attacks or imminently threatened attacks, not speculative gathering dangers that might only materialize in the future. Indeed, the real lesson of Munich is the lack of political will in Britain and France to forge a strong multilateral alliance with the Soviet Union to stand up to Hitler, which might have avoided war and led to Hitler's downfall within Germany. Indeed, such a strong defensive alliance, not preventive war, was the policy Churchill unsuccessfully advocated in the $1930 .^{111}$

While one must be cautious about drawing conclusive lessons from contested history, the evidence supports the decision of the drafters of the U.N. Charter to reject preventive war. ${ }^{12}$ First, the preventive rationale has often been a pretext masking an aggressive intent. The Nazis' reliance on preventive-war thinking, for example, was plainly a pretext for aggression.

Second, the preventive rationale has often led countries to be overeager to initiate what have turned out to be "fruitless" military campaigns. Many preventive wars have been launched on the deeply felt, but often erroneous perception that war was inevitable, and that a new threat had created a new strategic environment requiring bold, decisive action. While some preventive wars may have been necessary, and sometimes nations should have fought when instead they waited for the threat to materialize, the prominent scholar of the history of warfare, Columbia professor Robert Jervis, concluded that, "on balance, it seems that states are more likely to overestimate the hostility of others then to underestimate it." 113

109. David S. Cloud, Rumsfeld Says War Critics Haven't Learned Lessons of History, N.Y. Times, Aug. 30, 2006, at A4; Peter Baker \& Jim VandeHei, Bush Team Casts Foes as Defeatist, Wash. Post, Aug. 31, 2006, at A1.

110. Bret Baier, Rumsfeld: Attack Can't Wait, Fox News, Aug. 20, 2002.

111. Id. at 311; Winston S. Churchill, The Gathering Storm 210 (1948); Tuvia Ben-Moshe, Churchill, Strategy and History 108-09 (1992); A.P. Taylor, Churchill: Four Faces and the MAN 28-31 (1969).

112. U.N. CHARTER pmbl.

113. Robert Jervis, War and Misperception, J. InTER DISC. Hist. 688 (Spring 1988). 
Third, many preventive wars have been initiated, like the Iraq War, under the illusion that they would be short. That illusion fundamentally skews the cost-benefit analysis that a nation undertakes in deciding whether to launch a war. Rather than leading to quick, relatively costless victories, most preventive wars have had disastrous results. War is of course always costly, in lives and resources, but a preventive war is at least potentially an avoidable war. If the aggressor nation miscalculates and the nation it attacks was not in fact preparing to attack it, then the war is unnecessary. Wars undertaken in self-defense, by contrast, are almost by definition unavoidable.

Fourth, this history suggests that we should be suspicious of arguments that we are in a "new world," 114 facing "a threat with no precedent" 115 and that we should abandon the old rules in favor of a "new doctrine," or "new paradigm." 116 The use of an invocation of a new threat without precedent to argue that we should abandon the old legal rules is itself not new, and the argument ignores the fact that the rule against unilateral preventive warfare developed in large part in response to the world's generally disastrous experience of launching wars to prevent perceived new and unprecedented threats. That experience led the U.N. to adopt the principle that unilateral wars could be undertaken only in self-defense, in response to an armed attack. ${ }^{117}$ In recognition of the historic dangers of preventive war, the Charter imposes institutional restraints that permit resort to such warfare only when a state can convince the Security Council that such a war is necessary. ${ }^{118}$

\section{The Cold War and Preventive War Thought in the United States}

These same lessons of history have informed U.S. war policy at least since World War II, although not without debate. During the Cold War, U.S. policymakers continually grappled with arguments for preventive war remarkably similar to those made today. ${ }^{119}$

The ink was barely dry on the U.N. Charter when the world irrevocably and dramatically changed. Truman's decision to drop atomic bombs on the Japanese cities of Hiroshima and Nagasaki created a "paradigm shift" in

114. National Security Strategy, supra note 1 , at 4.

115. West Point, New York, 1 Pub. Papers 917, 919 (June 1, 2002).

116. See notes 26 and 27 supra.

117. U.N. CHARTER art. 51.

118. U.N. CHARTER arts. 39-42.

119. See discussion infra The Cold War and Preventive Thought in the United States. 
which government officials faced an unprecedented challenge not anticipated by the framers of the U.N. Charter. That challenge was at least as new and as daunting in their time as the danger posed by terrorists is today.

Between 1945 and 1949, the United States maintained a monopoly on atomic weapons, but the Soviet Union clearly was determined to break that monopoly. ${ }^{120}$ While some in the Truman administration urged that we share our atomic secret with the Soviets and develop a co-operative approach to nuclear weapons, a number of high level U.S. officials, particularly within the military and defense department, favored a policy of preventive war. ${ }^{121}$ Their argument, strikingly similar to those made for preventive war against Iraq and other rogue states, was that the Soviets were led by a brutal, paranoid, and aggressive dictator bent on world domination and that upon reaching atomic parity with the United States, the Soviets would inevitably launch a surprise attack against us. ${ }^{122}$ Therefore, a better alternative was to launch a war to prevent them from obtaining nuclear weapons, rather than delay until it was too late. As early as January 1946, General Leslie Groves, the wartime head of the Manhattan Project, raised the desirability of preventive war. "If we were ruthlessly realistic," he wrote,

we would not permit any foreign power with which we are not firmly allied, and in which we do not have absolute confidence, to make or possess atomic weapons. . . . If such a country started to make atomic weapons we would destroy its capacity to make them before it had progressed far enough to threaten us. ${ }^{123}$

General Orvil Anderson, the commandant of the Air War College, agreed with Groves that the changed nature of war meant that an "overt act of war has been committed by an enemy when [it] builds [weapons] intended for our eventual destruction" and therefore, destroying those weapons "before [they] can be launched or employed is defensive action and not aggression." 124

120. Copeland, supra note 54, at 170.

121. See generally McGeorge Bundy, Danger and Survival: Choices about the Bomb in the First Fifty Years 130-96 (1988) (explaining Truman's decision process); Copeland, supra note 54, at 162-68 (discussing the administration's considerations in adopting a co-operative approach); TrAChtenBerg, supra note 58, at 100-53 (explaining the differing views within the Truman administration).

122. TRACHTENBERG, supra note 58 , at 100-53.

123. Jeffrey Record, Nuclear Deterrence, Preventive War, and Counterproliferation, PoL'Y ANAL YSIS, July 8, 2004, at 1, 14 (internal quotation marks omitted).

124. Gian P. Gentile, Planning for Preventive War, 1945-1950, JoInT ForCE Q., Spring 2000, at 68, 70. 
Indeed, preventive war logic was quite common not only among military officials, but also among civilian leaders, who believed that war with the Soviets was inevitable and that sooner was better than later. ${ }^{125}$ Many agreed with William L. Laurence, a science correspondent for the New York Times and America's leading writer on nuclear issues, when he wrote in 1948 that Soviet "insistence on an atomic-armament race . . must inevitably lead to war," and that "it would be to our advantage to [fight] it while we are still the sole possessors of the atomic bomb." ${ }^{26}$ Laurence argued that we should present the Soviets with an ultimatum to dismantle their atomic plants, and if they refused, destroy their plants before the bombs could be produced. ${ }^{127}$ Senator Brian McMahon, the influential Chairman of the Joint Committee of Atomic Energy, favored the idea, arguing that "almost nothing could be worse than the current atomic armaments race." 128 Influential intellectuals such as Bertrand Russell and the famous physicist Leo Szilard supported preventive war arguments, as did noted mathematicians such as John Williams, a leading figure at the RAND Corporation, and John von Neumann, the founder of game theory. ${ }^{129}$ Von Neumann was a particularly strong advocate, remarking in 1950 that "[i]f you say why not bomb them tomorrow, I say why not today? If you say today at 5 o'clock, I say why not one o'clock?"130

While preventive war thinking found support in both military and civilian circles, it was especially strong within the Defense Department. Some military officials made the identical argument that Secretary of Defense Rumsfeld makes today. They asserted that the new "complexion of atomic war reemphasizes the old cliché that the best defense is a good offense and alters it somewhat: [T] he best defense is the first offense in force." ${ }^{\prime 131}$ Similarly, the argument that the atomic era rendered surprise attacks indefensible by traditional defensive means surfaced in 1947 in a report by the Joint Chiefs of Staff advocating reorientation of national military strategy to permit preventive war. ${ }^{132}$ The report urged America to revise its

125. TrachtenBerg, supra note 58, at 103-04.

126. William L. Laurence, How Soon Will Russia Have the A-Bomb?, SAturday Evening Post, Nov. 6, 1948, at 182; TRAChtENBERG, supra note 58, at 103.

127. Laurence, supra note 126.

128. TRACHTENBERG, supra note 58, at 103-04.

129. $I d$.

130. Id. at 104 (internal citation and quotation marks omitted).

131. Gentile, supra note 124, at 72 (internal citation and quotation marks omitted).

132. Joint Chiefs of Staff, The Final Report of the Joint Chiefs of Staff Evaluation Board for Operation Crossroads (1947), reprinted in 9 America's Plans for War Against the Soviet Union 1945-1950, at 110-11 (David A. Rosenberg \& Stephen T. Ross eds., 1989). 
traditional attitudes toward what constitute acts of aggression so that our armed forces may plan and operate in accordance with the realities of atomic warfare. Our policy of national defense must provide for the employment of every practical means to prevent surprise attack. Offensive measures will be the only generally effective means of defense, and the United States must be prepared to employ them before a potential enemy can inflict significant damage upon us. ${ }^{133}$

In August 1950, Secretary of the Navy Francis Matthews openly urged the United States to adopt a "character new to a true democracy-an initiator of a war of aggression - it would win for us a proud and popular title-we would become the first aggressors for peace." "134 "The United States should be willing to pay any price to achieve a world at peace," Matthews proclaimed, "even the price of instituting a war to compel cooperation for peace."135 Matthews' speech, which was believed to be a trial balloon launched at the behest of his boss, Secretary of Defense Louis Johnson, ${ }^{136}$ was followed less than a week later by an even more explosive public statement by General Orville Anderson, commandant of the Air War College. ${ }^{137}$ Anderson told a columnist for the Montgomery Advertiser that he favored a preventive war to destroy the incipient Soviet nuclear facilities:

"Give me the order to do it and I can break up Russia's five A-bomb nests in a week," he said. "And when I went to Christ, I think I could explain to Him why I wanted to do it now before it's too late. I think I could explain to Him that I had saved civilization. With it [the A-bomb] used in time, we can immobilize a foe [and prevent] his crime before it happened." 138

President Truman, however, decisively rejected a policy of preventive war. He personally chastised Matthews and fired Anderson the day after his interview was reported. ${ }^{139}$ "We do not believe in aggressive or preventive war," Truman said in a radio broadcast the next day, "[s]uch war is the

133. Id.

134. Matthews Favors U.S. War for Peace, N.Y. Times, Aug. 26, 1950, at 1 (internal quotation marks omitted).

135. Id. (internal quotation marks omitted).

136. Hanson W. Baldwin, War of Prevention: Perils in Proposed Attack on Soviets Now Are Weighed Against Alleged Advantage, N.Y. Times, Sept. 1, 1950, at 4.

137. Record, supra note 123 , at 14.

138. Id.

139. Steven R. Prebeck, Preventive Attack in the 1990s?, 8, 9 (May 28, 1993) (unpublished thesis, School of Advanced Airpower Studies) (on file with Air University Press, Maxwell Air Force Base, Alabama). 
weapon of dictators, not of free democratic countries like the United States." $" 140$

By 1949, the Soviets had exploded their first atomic weapon, which, in the words of Dean Acheson "changed everything." 141 The Truman administration undertook a comprehensive review of United States military policy. The results of that review were set forth in NSC-68, which described the Soviets as being driven by "a new fanatic faith that seeks to impose its absolute authority over the rest of the world." 142 NSC-68 rejected the views of those like George Kennan who advocated negotiations with the Soviets, in favor of a rapid, massive military build-up of both conventional forces and nuclear forces through the construction of new super atomic, hydrogen bombs. The militaristic policy urged by NSC- 68 and adopted by Truman required massive military spending heretofore unheard of in peacetime.

Despite its strongly militaristic recommendations, NSC-68 explicitly considered and rejected preventive war. It offered three reasons for doing so. First, it would not work. A U.S. atomic attack on the U.S.S.R. "would not force or induce the Kremlin to capitulate and ... the Kremlin would still be able to use the forces under its control to dominate most or all of Eurasia."'143 Second, a preventive attack "would be repugnant to many Americans," leading to domestic opposition. ${ }^{144}$ Third, U.S. allies, particularly in Western Europe, would also oppose such a war, harming U.S. relations with them and making it "difficult after such a war to create satisfactory international order." 145 The conclusion was that the United States should not launch an attack unless attacked or facing imminent attack: "These considerations are no less weighty because they are imponderable, and they rule out an attack unless it is demonstrably in the nature of a counter-attack to a blow which is on its way or about to be delivered." 146

Despite Anderson's firing and the NSC-68's rejection of preventive war, many U.S. generals and other high level military officials continued to support the concept in private. Within several years, the Eisenhower administration

140. Text of Truman's 'Report to Nation' on Korean War, N.Y. Times, Sept. 2, 1950, at 4.

141. LAFEBER, supra note 63, at 479 (internal quotation marks omitted).

142. Id. at 480 (internal quotation marks omitted).

143. NSC 68, reprinted in 1 Foreign Relations of the United States, 1950, at 281-82, quoted in Scott D. Sagan, The Perils of Proliferation: Organization Theory, Deterrence Theory, and the Spread of Nuclear Weapons, InT'L SECURITY, Spring 1994, at 66, 78.

144. Id.

145. $I d$.

146. Sagan, supra note 143, at 78-79 (quoting NSC 68, reprinted in 1 ForeIgn ReLATIONS OF THE United States, 1950, at 281-82). 
revisited the arguments for preventive war. In an August 1953 memorandum to the Joint Chiefs of Staff, General Nathan Twining, Air Force Chief of Staff and later Chairman of the Joint Chiefs of Staff, argued for a preventive war prior to the Soviet's development of nuclear weapons sufficient to destroy us:

We must recognize this time of decision, or, we will continue blindly down a suicidal path and arrive at a situation in which we will have entrusted our survival to the whims of a small group of proven barbarians. If we believe it unsafe, unwise, or immoral to gamble that the enemy will tolerate our existence under this circumstance, we must be militarily prepared to support such decisions as might involve general war. ${ }^{147}$

In 1954, the Joint Chiefs of Staff criticized what they viewed as the essentially reactive and defensive nature of U.S. policy, urging that a policy of an "unmistakenly positive quality" be adopted. ${ }^{148}$ As Joint Chiefs of Staff ("J.C.S.") Chairman Radford explained to the National Security Council in November 1954, "if we continue the policy of forestalling Communist action, we cannot hope for anything but a showdown with Soviet Communists by 1959 or 1960." Victory in a nuclear war could be guaranteed only if it occurred "prior to Soviet achievement of atomic plenty." 149 In May 1954, the J.C.S. Advance Study Group briefed President Eisenhower on a proposal that the United States consider "“deliberately precipitating war with the U.S.S.R. in the near future,' before Soviet thermonuclear capability became a 'real menace." "150

President Eisenhower decisively rejected the argument for preventive war, as had Truman. Eisenhower's Army Chief of Staff, Matthew Ridgeway, denounced the policy as "contrary to every principle upon which our Nation had been founded," and "abhorrent to the great mass of American people."151 Secretary of State John Foster Dulles argued that containment was working, adding sarcastically, "even if it hasn't got us into a war." 152 While Eisenhower himself had raised in a 1953 private memo to Dulles, the thought that the continued arms race might "either drive us to war . . . or into some form of dictatorial government[,]" forcing us to consider whether "to initiate war at

147. $I d$. at 80 (internal citations and quotation marks omitted).

148. BUNDY, supra note 121, at 251.

149. Sagan, supra note 143 , at 80.

150. David Alan Rosenberg, The Origins of Overkill: Nuclear Weapons and American Strategy, 1945-1960, InT'L SECURITY, Spring 1983, at 3, 34.

151. Id. at 34 .

152. Bundy, supra note 121, at 251 (internal quotation marks omitted). 
the most propitious moment that we could designate." ${ }^{53}$ However, he decisively rejected the idea of preventive war:

All of us have heard this term "preventive war" since the earliest days of Hitler . . . . A preventive war, to my mind, is an impossibility today .... I don't believe there is such a thing; and frankly, I wouldn't even listen to anyone seriously that came in and talked about such a thing. ${ }^{154}$

When asked later by Washington Post journalist Chalmers Roberts whether he was opposed to preventive war only for "military reasons," Eisenhower responded that "[t]here are all sorts of reasons, moral and political and everything else, against this theory, but it is so completely unthinkable in today's conditions that I thought it is no use to go any further."155

An updated Basic National Security Policy approved by Eisenhower in late 1954 and early 1955 stated unequivocally that "[t]he United States and its allies must reject the concept of preventive war or acts intended to provoke war." 156 The rejection of preventive war remained official U.S. policy throughout the Cold War. As Professor Bernard Brodie, the preeminent national security scholar of the 1940 s and ' $50 \mathrm{~s}$, wrote, "[t]he people of the United States have obviously made a decision, with little overt debate but quite remarkable unanimity, against any form of preventive war . . . [A] decision ... which accords profoundly with our national psychology and system of values."157 Even future Secretary of State Henry Kissinger concurred, dismissing the idea of preventive war in 1955 with the comment that " $[t]$ here has always been an air of unreality about a program so contrary to the sense of the country and the constitutional limits within which American foreign policy must be conducted." 158

Brodie may have been over-optimistic about Americans' inherent sense of values. In the late 1940s, polls indicated that 70 percent of the American people supported the first use of atomic weapons and preventive war. ${ }^{159}$ However, by the mid 1950s, only 13 percent agreed in a Gallup Poll with the

153. Memorandum by the President to the Secretary of State, September 8, 1953, reprinted in 2 Foreign Relations of the United States, 1952-1954, at 461.

154. The President's News Conference of August 11, 1954, 1 Pub. PAPERs 696, 698 (Aug. 11, 1954). 155. Id. at 701-02.

156. NSC 5501, reprinted in 2 Foreign Relations of the United States, 1955-1957, at 33.

157. Bernard Brodie, Strategy in the Missile Age 392 (1959).

158. Harry S. Laver, Preemption and the Evolution of America's Strategic Defense, J. U.S. ARMY WAR C. Q., Summer 2005, at 107, 114 (internal citations and quotation marks omitted).

159. Prebeck, supra note 139, at 9 (citing various Gallup Polls). 
view that we should launch a preventive war against the Soviet Union while we had the advantage in atomic weapons. ${ }^{160}$

The closest the United States ever came to launching a preventive war against the Soviet Union or its allies during the Cold War came in the Cuban Missile Crisis. The Bush administration invokes President Kennedy's handling of that crisis as precedent for its policy of preventive war. "Think of John F. Kennedy in the Cuban Missile Crisis," Secretary of State Donald Rumsfeld argues. "He didn't sit there and let Soviets put missiles in Cuba and fire a nuclear missile at the United States; he decided to engage in preemptive action, preventative action, anticipatory self defense, call it what you wish. And he went out and blockaded them .... And prevailed because he did take preventive action." $" 161$

However, Rumsfeld's invocation of Kennedy is inapt for two critical reasons. First, Kennedy explicitly rejected the option of a preventive military strike against Cuba, despite the urgings of the Joint Chiefs of Staff and many of his civilian advisors. ${ }^{162}$ Instead, Kennedy authorized a minimal use of force, the quarantine or blockade, with the resolve to seek a diplomatic, not a military solution to the crisis. ${ }^{163}$ That diplomatic resolution involved substantial concessions, including an agreement not to invade Cuba, a promise that provoked severe criticism from the President's conservative critics. ${ }^{164}$

The Cuban Missile Crisis began with the type of strategic threat that had led to many a preventive war in the past: action by an inferior military power, in this case the Soviet Union, to challenge the United States' overwhelming dominance in intercontinental range nuclear weapons, by placing nuclear weapons 90 miles from U.S. territory. The Joint Chiefs of Staff and many civilian advisors, including Dean Rusk, McGeorge Bundy, Max Taylor, former Secretary of State Dean Acheson, Treasury Secretary Douglas Dillon, argued for immediate airstrikes to destroy the nuclear missile sites in Cuba, followed by preparations for invasion. ${ }^{165}$ At first, the President appeared to lean toward quick military action. The probability of military success was thought to be high. America's nuclear and conventional military supremacy

160. $I d$.

161. Interview by John Shirek with Donald Rumsfeld, Secretary of Defense, United States of America (Sept. 27, 2002), available at http://www.pentagon.mil/transcripts/2002/t09302002_t927wxia.html.

162. KAGAN, supra note 59 , at 516-22.

163. Id. at 521-22.

164. Id.

165. Id. at 515-16. 
in the Caribbean meant that there was little chance for the Soviets or Cubans to defend the island.

Nevertheless, such military action could easily have led to all out war, and the President sought an option that "lessen[ed] the chances of a nuclear exchange which obviously is the final failure." 166 In addition, the President and his advisors were reportedly influenced by the argument that a preventive attack would be analogous to the Japanese attack on Pearl Harbor, and, therefore, as Undersecretary of State George Ball argued, "contrary to our traditions ... directly thwart [what] we have stood for during our national history," and perhaps, most tellingly, would "condemn us as hypocrites in the opinion of the world." 167 Robert Kennedy referred in various meetings to the Pearl Harbor analogy, passing a note to his brother at the very first executive meeting discussing a preemptive airstrike, "I now know how Tojo felt when he was planning Pearl Harbor." 168 At a crucial meeting on September 19, 1962, Robert Kennedy made what historian Donald Kagan views as a "decisive intervention" in the debate. ${ }^{169}$ The young Attorney General made clear that the President rejected the airstrike option, stating that he had spoken with him that morning and later recounted:

he thought it would be very difficult indeed for the President if the decision were to be for an air strike, with all the memory of Pearl Harbor and with all the implications this would have for us in whatever world there would be afterward. For 175 years we had not been that kind of country. ${ }^{170}$

When President Kennedy met with his advisors the next day, he confirmed that he had decided on the blockade and had ruled out immediate military action, calling it "the only course compatible with American principles."

Thus, Kennedy essentially rejected the notion of a preventive attack in favor of a quarantine aimed toward diplomatic resolution. Most observers believe that even had Khrushchev declined to remove the missiles immediately, Kennedy would have offered the dismantling of U.S. missiles in Turkey for the dismantling of Soviet missiles in Cuba (a proposal that

166. Copeland, supra note 54, at 194.

167. Record, supra note 123, at 13-14 (internal quotation marks omitted).

168. KAGAN, supra note 59, at 517 (internal quotation marks omitted).

169. Id.

170. $I d$.

171. $I d$. at 520 (internal quotation marks omitted). 
Kennedy did agree to privately) or would have tightened the naval blockade, but would not have proceeded with air strikes against Cuba. ${ }^{172}$

In the end, Khrushchev backed down and removed the missiles from Cuba, but only with a public promise from the Kennedy administration not to invade Cuba and a secret, private agreement to remove U.S. missiles from Turkey. As Abram Chayes, a State Department official during the crisis, later noted, the trade of Cuban for Turkish missiles meant that the crisis was resolved by a decision to "in part, buy 'em out," a fact "talked about much less ... because of the power of the Munich stigma and because it sounds a lot less courageous." 173 McGeorge Bundy, one of the hawks in Kennedy's inner circle, said immediately after the resolution of the crisis that "this was the day of the doves," ${ }^{174}$ while Air Force Chief Curtis LeMay, a strong supporter of preventive war, angrily called the agreement between Khrushchev and Kennedy, "the greatest defeat in our history." 175 The Cuban Missile Crisis, then, provides no support whatsoever for advocates of preventive invasions of the sort launched against Iraq.

Indeed, President Kennedy's actions during the Cuban Missile Crisis expose the false dichotomy between action and inaction that permeates so much of the Bush administration's rhetoric in support of preventive war. As Robert Kennedy argued, the choice was not between a preemptive strike and inaction. Kennedy "favored action" to make known unmistakably the seriousness of the United States' determination to get the missiles out of Cuba, but it was action that left room for a diplomatic solution, as opposed to launching a war. ${ }^{176}$ In hindsight, it is hard to see how America would be safer had Kennedy followed the recommendations of the Joint Chiefs and launched a preventive attack.

The second important difference between Kennedy's approach to the Cuban Missile Crisis and Bush's position is that Kennedy did not seek to justify his actions with a new doctrine of preventive self-defense. Instead, the Kennedy administration repeatedly and consciously rejected reliance on selfdefense, despite the urgings of former Secretary of State Dean Acheson and Deputy Attorney General Nicholas Katzenbach that international law could be read in the atomic age to permit a self-defense justification. ${ }^{177}$ The reason

172. Bundy, supra note 121 , at 435, 439; KAGAN, supra note 59, at 541-42.

173. KAGAN, supra note 59, at 543 (internal quotation marks omitted).

174. Id. at 545 (internal quotation marks omitted).

175. Id. at 546 (internal quotation marks omitted).

176. $I d$. at 517 (internal quotation marks and emphasis omitted).

177. Abram Chayes, The Cuban Missile Crisis: International Crises and the Role of LaW 
that the Kennedy administration avoided reliance on preventive self-defense was best explained by Abram Chayes, the legal advisor to the State Department during the Cuban Missile Crisis. Chayes accepted that the notion of self-defense included an anticipatory response to an imminent attack. But to permit preventive self-defense where there is no threatened imminent attack, he maintained, would mean that " $[\mathrm{t}]$ here is simply no standard against which this decision could be judged. Whenever a nation believed that its interests, which in the heat and pressure of a crisis it is prepared to characterize as vital, were threatened, its use of force in response would become permissible." ${ }^{178}$

Instead of self-defense, the administration explicitly rested its argument for the quarantine on the Organization of American States' (OAS) approval of the action, which Robert Kennedy later said transformed the U.S. position "from that of an outlaw acting in violation of international law into a country acting in accordance with twenty allies legally protecting their position." 179 Whether Kennedy was correct that the OAS approval provided legal justification for the blockade has been disputed; what is indisputable is that Kennedy eschewed the doctrine of preventive self-defense.

The Kennedy and Johnson administrations also briefly considered preventive war against China in the 1960s. President Kennedy and his National Security Advisor, McGeorge Bundy, believed that Chinese possession of nuclear weapons would be intolerable because Mao Tse Tung would be emboldened to commit blackmail and aggression. ${ }^{180}$ Kennedy reportedly felt that a successful Chinese nuclear test was likely to be "the most significant and worst event of the 1960s." Alsop argued in the Saturday Evening Post that the "madness of Mao TseTung" required military action against Beijing's nuclear program, which he characterized as a "technically easy problem" that could be accomplished with a "few rather small bangs." 182 A lengthy article in the National Review argued that a preemptive strike on Chinese nuclear installations could be warranted in the future, and that such a strike could be justified "as a unique response to

\footnotetext{
15, 63-64 (1974).

178. Id. at 65.

179. Robert F. Kennedy, Thirteen Days 121 (1969).

180. Record, supra note 123, at 15.

181. William Burr \& Jeffrey T. Richelson, Whether to "Strangle the Baby in the Cradle": The United States and the Chinese Nuclear Program, 1960-64, InT'L SECURITY, Winter 2000/2001, at 54, 61. 182. Id. at 74 (internal quotation marks omitted).
} 
a unique situation not yet covered by international law[,]" the same justification offered by the Bush administration for its new doctrine. ${ }^{183}$

Kennedy's advisor, McGeorge Bundy claims that there was talk in Washington about the possibility of preemptive action against the Chinese bomb, but that it was only talk, not serious planning or real intent. ${ }^{184}$ Historians have been skeptical about Bundy's claim, arguing that newly declassified documents show that Kennedy and his advisors did more than talk. ${ }^{185}$ Nonetheless, President Johnson subsequently rejected proposals for preventive strikes against China as both unwise and impractical. ${ }^{186}$

Finally, in several instances involving Libya and North Korea, the United States threatened military action against facilities that the it believed could produce chemical or nuclear weapons. ${ }^{187}$ While the United States apparently threatened North Korea with such action, President Clinton's top military and civilian advisors decided against actually launching such an attack in the event North Korea did not back down. Their reasoning was that although the immediate objective of destroying the North Korean nuclear facilities could have been easily achieved, a preemptive attack might well have triggered a second Korean war, in which hundreds of thousands of lives would have been lost. ${ }^{188}$ In any event, both North Korea and Libya backed down and in neither of these instances did the threat eventuate.

President Bush has argued that today we face a threat with no precedent, and that therefore, history is less relevant. ${ }^{189}$ However, the history of preventive war demonstrates that President Bush is not alone in this assessment; nations that launch preventive wars invariably perceive that they are faced with some unprecedented threat which they believe will inevitably destroy them unless decisive, forceful action is taken immediately. ${ }^{190}$ The hazardous unpredictability of that judgment is no less true today; no indication exists that the war against terrorism has sharpened humans' ability to predict

183. Robert M. Lawrence \& William R. Van Cleave, Assertive Disarmament, NAT'L ReV., Sept. 10, 1968 , at 898,901 .

184. BUNDY, supra note 121 , at 532.

185. Burr \& Richelson, supra note 181, at 55.

186. Record, supra note 123, at 15.

187. M. Elaine Bunn, Preemptive Action: When, How and to What Effect, Stra TEg IC Forum \#200, National Defense University, July 2003, at 2; Elaine Monaghan, Clinton Planned Attack on Korean Nuclear Reactors, The Times (London), Dec. 16, 2002, at 12.

188. Ashton B. Carter \& William J. Perry, Preventive Defense: A New Security Strategy FOR AMERICA 128, 131 (1998).

189. Press Release, supra note 13.

190. See discussion infra. 
the future. Moreover, as has been shown, proposals to launch preventive wars against evil, maniacal dictators seen as driven to destroy us, and who possess or are seeking to develop weapons of mass destruction are not new. Stalin and Mao were viewed in their day as no less paranoid monsters than Saddam Hussein is today. Nevertheless until the recent war with Iraq, no U.S. administration had launched such a preventive war.

The administration also claims that while deterrence worked during the Cold War where we faced a "generally status quo, risk-averse adversary," the "threat of retaliation is less likely to work against leaders of rogue states more willing to take risks, gambling with the lives of their people, and the wealth of their nation." ${ }^{\prime 191}$ Yet during the late 1940s and early 1950s when preventive war thought in the United States was most prevalent, most military or civilian leaders would not have described Stalin's Soviet Union or Mao's China as "generally status-quo, risk averse adversary." It is only in hindsight that we now know that deterrence worked during the Cold War, just as we now know that Saddam Hussein had no weapons of mass destruction threatening us or his neighbors. The historical record demonstrates that nations often misjudge their adversaries' intentions and launch wars because they assume that their adversaries are unwilling to preserve the status quo and have aggressive designs against them..

Finally, it may well be that the primary reason that the Truman, Eisenhower, Kennedy and Johnson administrations refused to launch preemptive strikes against the Soviet Union and China was not for moral, ethical, or legal reasons, but because of the serious danger of triggering nuclear destruction or a major war. But this in turn demonstrates the bankruptcy of the preventive war doctrine. Preventive war is especially unwise against a foe that is really a serious threat and has the capability of involving the United States in a lengthy and destructive conflict. In other words, the doctrine is least likely to be used where its use would be most theoretically justified: against those countries that most threaten us. The risks presented by such a conflict would seem to eliminate preventive war as an option against the very nations President Bush has identified as rogue states, such as Iran, North Korea, or Cuba, and certainly would rule out preventive war against any nation State that actually possesses significant weapons of mass destruction like Pakistan. Indeed, even in Iraq, which had no weapons of mass destruction, it turns out that preventive war is much messier, lengthy, and destructive than our leaders ever imagined. 
That the United Stated rejected the preventive war doctrine during the Cold War is not to suggest that our government always followed international law during that era. The United States and the Soviet Union repeatedly violated the U.N. Charter's prohibitions on the use of force; the Soviet invasions of Hungary, Czechoslovakia, and Afghanistan and the U.S. invasions of Nicaragua, the Dominican Republic, Grenada, Libya, and Panama are just a few examples. Nonetheless, both the United States and the Soviet Union maintained a formal fealty to the principle that force not be used unilaterally except in self-defense to an attack or imminent attack. While both nations sought to expand the self-defense exception, defining the concept of armed attack broadly to include aid a state provides to insurgents in an allied nation, or asserting an expansive right to protect nationals abroad, both superpowers had an interest in the stability of the formal rules stemming from World War II. Neither desired the destabilizing effects that openly challenging the Charter rule would bring. ${ }^{192}$

The end of the Cold War demise of the Soviet Union has left us with enormous, unchallenged power. It is in significant part that dominant power that made it possible for the Bush administration to adopt preventive-war strategies that were repeatedly rejected during the Cold War. As conservative columnist Charles Krauthammer points out, what is "new is what happened not on 9/11 but ten years earlier on December 26, 1991: the emergence of the United States as the world's unipolar power." 193 The adoption of the preventive war strategy is a reflection of that unchallenged power. That dominance is likely to keep preventive war as a policy option for future administrations - whether they be Democratic or Republican. ${ }^{194}$

But we should resist that option. By threatening to attack countries that have neither attacked us nor threatened an attack, the Bush administration has ignored the historical dangers of preventive war that undermine the rule of law and our security.

192. Lobel, supra note 2, at 20-22

193. Charles Krauthammer, Democratic Realism: An American Foreign Policy for a UNIPOLAR WORLD 18 (2004).

194. See, e.g., Ashton Carter \& William J. Perry, If Necessary, Strike and Destroy: North Korea Cannot Be Allowed to Test This Missile, Wash. Post, June 22, 2006, at A29 (former Clinton administration secretary of defense and assistant secretary of defense urge a preemptive military strike against North Korea); David Rieff, But Who's Against the Next War, N.Y. TimEs, Mar. 25, 2007, § 6, at 13. 


\section{CONCLUSION}

The United Nations Charter prohibition on nation's International Law's judgment that it is better to avoid warfare unless a nation either has no choice but to defend itself from an attack or imminent attack, or can convince a majority of nations on the Security Council that another nation presents such a clear danger and threat that an internationally sanctioned war should be fought on behalf of the community of nations. The historical experience described in this essay cannot prove the validity of that judgment made by international law, but it does provide evidence supporting that judgment. So too does our war against Iraq, in which government leaders repeated the experience of many prior preventive wars, exaggerating the risk posed by the other nation and underestimating the costs of war.

Some scholars, such as Professors Michael Glennon and John Yoo, have argued that history also demonstrates that the Security Council has proven to be a failure, undermined by repeated violations of its prohibitions on the use of force. ${ }^{195}$ To them, this historical failure of the Security Council undermines the Charter's legal regime.

In fact, the Security Council performed its functions in the Iraq case as it was designed to do. The Council imposed a strict inspection process on Iraq. ${ }^{196}$ The inspectors set about their work and were unable to find any Iraqi weapons of mass destruction. The Council accordingly determined that the inspections should continue. The Council's judgment accurately reflected the overwhelming international consensus. In the end, the United States was not even able to muster a majority vote to approve a resolution that could be read as authorizing war. Even countries usually allied with the United States, such as Mexico, Chile, Germany and France, refused to authorize preventive war. ${ }^{197}$ The Security Council performed its task admirably, seeking to resolve the dispute peacefully. But against the will of the Security Council and most of the world, the United States and Great Britain attacked Iraq anyway. That is Glennon and Yoo's main point: the lessons of history demonstrate that strong nations simply do not accept legal or institutional restraints on their power to

195. John C. Yoo \& Will Trachman, Less than Bargained for: The Use of Force and the Declining Relevance of the United Nations, 5 CHI. J. INT'L L. 379, 381 (2005); Michael Glennon, Why the Security Council Failed, Foreign AfFairs, May/June 2003, at 22-23.

196. U.N. Sec. Res. 1441 (Nov. 8, 2002).

197. Glenn Kessler \& Mike Allen, U.S. Missteps Led to Failed Diplomacy, Wash. Post, Mar. 16, 2003, at A15; David E. Sanger \& Warren Hoge, Threats and Responses: Diplomacy; Bush and 2 Allies Seem Set for War to Depose Hussein, N.Y. TimES, Mar. 17, 2003, at A1; Felicity Barringer, Threats and Responses: Security Council, N.Y. Times, Mar. 18, 2003, at A21. 
use force to protect what they consider their own vital interests. As Thucydides put it more than two thousand years ago, "the strong do what they can and the weak suffer what they must." ${ }^{198}$

Glennon and Yoo's reading of history leads them to conclude that a stable international order does not depend primarily on the rule of law, but, as Yoo puts it, on "hegemonic stability." Preventive military action launched by a hegemonic power or a group of nations to maintain peace may benefit all nations. The international system "should promote conduct that encourages stability-enhancing uses of force, rather than seeking to reach a zero level of violence, as current rules do." ${ }^{199}$ Both Yoo and Glennon point to the 19th century British example, where the British Navy, twice as large as its nearest competitor, ruled the high seas, and used force aggressively and unilaterally to protect the freedom of the seas, allowing maritime transport and commerce to flourish. ${ }^{200}$

The world today is therefore grappling with two contradictory lessons from history. The first emphasizes the dangers of preventive war, while the second emphasizes the difficulty of developing institutional and legal checks on nations' resort to warfare. Yet despite the mixed record of the United Nations in controlling warfare and the gloomy predictions for its future made by some scholars and administration officials, the world simply cannot afford to abandon the United Nations' goal of preventing the scourge of war. The history of wars fought for ostensibly preventive reasons provides strong support for maintaining the Charter's rules.

198. ThuCYDIDES, supra note 66 , at 331.

199. Yoo, supra note 2, at 786.

200. Id. at 786-87. 